\title{
A microseismic study in a low seismicity area: the 2001 site-response experiment in the Città di Castello Basin (Italy)
}

\author{
Paola Bordoni $\left({ }^{1}\right)$, Giovanna Cultrera $\left({ }^{1}\right)$, Lucia Margheriti $\left({ }^{1}\right)$, Paolo Augliera $\left({ }^{1}\right)$, Grazia Caielli $\left({ }^{3}\right)$, \\ Marco Cattaneo $\left({ }^{1}\right)$, Roberto de Franco $\left({ }^{3}\right)$, Alberto Michelini $\left({ }^{1}\right)\left({ }^{2}\right)$ and Daniele Spallarossa $\left({ }^{4}\right)$ \\ (') Istituto Nazionale di Geofisica e Vulcanologia, Roma, Italy \\ (2) Istituto Nazionale di Oceanografia e di Geofisica Sperimentale \\ - Centro Ricerche Sismologiche (INOGS-CRS), Udine, Italy \\ $\left({ }^{3}\right)$ Istituto per la Dinamica dei Processi Ambientali (IDPA), CNR, Milano, Italy \\ $\left({ }^{4}\right)$ Dipartimento per lo Studio del Territorio e le sue Risorse (Dip.Te.Ris.), Università di Genova, Italy
}

\begin{abstract}
A site response experiment was performed in the basin of Città di Castello (a small town in Central Italy) in May 2001. This study is part of a project on the evaluation of seismic hazard in seismogenic areas funded by the Gruppo Nazionale Difesa dai Terremoti (GNDT). The experiment consisted of a dense fixed transect configuration with most of the stations recording in continuous mode, and several ambient noise measurements both in single station and in array configuration spread over the investigated area. The dense transect was composed of 26 seismic stations in a crosswise configuration with a maximum inter-station distance of 250 $\mathrm{m}$. The stations were deployed in the southern part of the basin, from the eastern bedrock outcrop to the western edge, across the town. About 70 earthquakes were recorded during 10 days of deployment, generally low magnitude or regional events. We located 23 earthquakes and 17 of them were located using the waveform similarity approach at 4 stations outside the target area. These 4 stations were part of a dense temporary seismic network involved in a previous experiment of the same project, aimed at performing a high-resolution picture of the local seismicity. Delay analysis on the recorded waveforms allowed us to infer the basin geometry at depth and estimate the $S$-wave velocity of sediments. Moreover, we evaluated relative site response along the $\mathrm{E}-\mathrm{W}$ transect by performing a standard spectral ratio. Amplification factors up to 9 are found inside the basin; at frequencies above $5 \mathrm{~Hz}$ stations closer to the edges show higher amplification, whereas stations located in the middle of the basin, where the alluvial sediments are thicker (CD11-CD14), show higher amplification below $5 \mathrm{~Hz}$. We considered the average amplification in two frequency bands $(1-5 \mathrm{~Hz}$ and $5-10$ $\mathrm{Hz}$ ), representative of the resonance frequency for 2-3 storey buildings and 1 storey houses, respectively. Our results suggest that the potential hazard for 2-3 storey buildings is higher in the center of the basin (amplification factor up to 6), and for 1 storey houses is higher at the edges (amplification factor up to 5).
\end{abstract}

Key words dense seismic array - weak motion ambient noise - basin geometry - urban area

Mailing address: Dr. Paola Bordoni, Istituto Nazionale di Geofisica e Vulcanologia, Via di Vigna Murata 605 , 00143 Roma, Italy; e-mail:bordoni@ingv.it

\section{Introduction}

The site response experiment in the Città di Castello (CDC) Basin, Umbria (Central Italy), was performed within the framework of the GNDT project «Development and comparison among methodologies for the evaluation of seismic hazard in seismogenic areas: application to the Central and Southern Apennines». This basin 


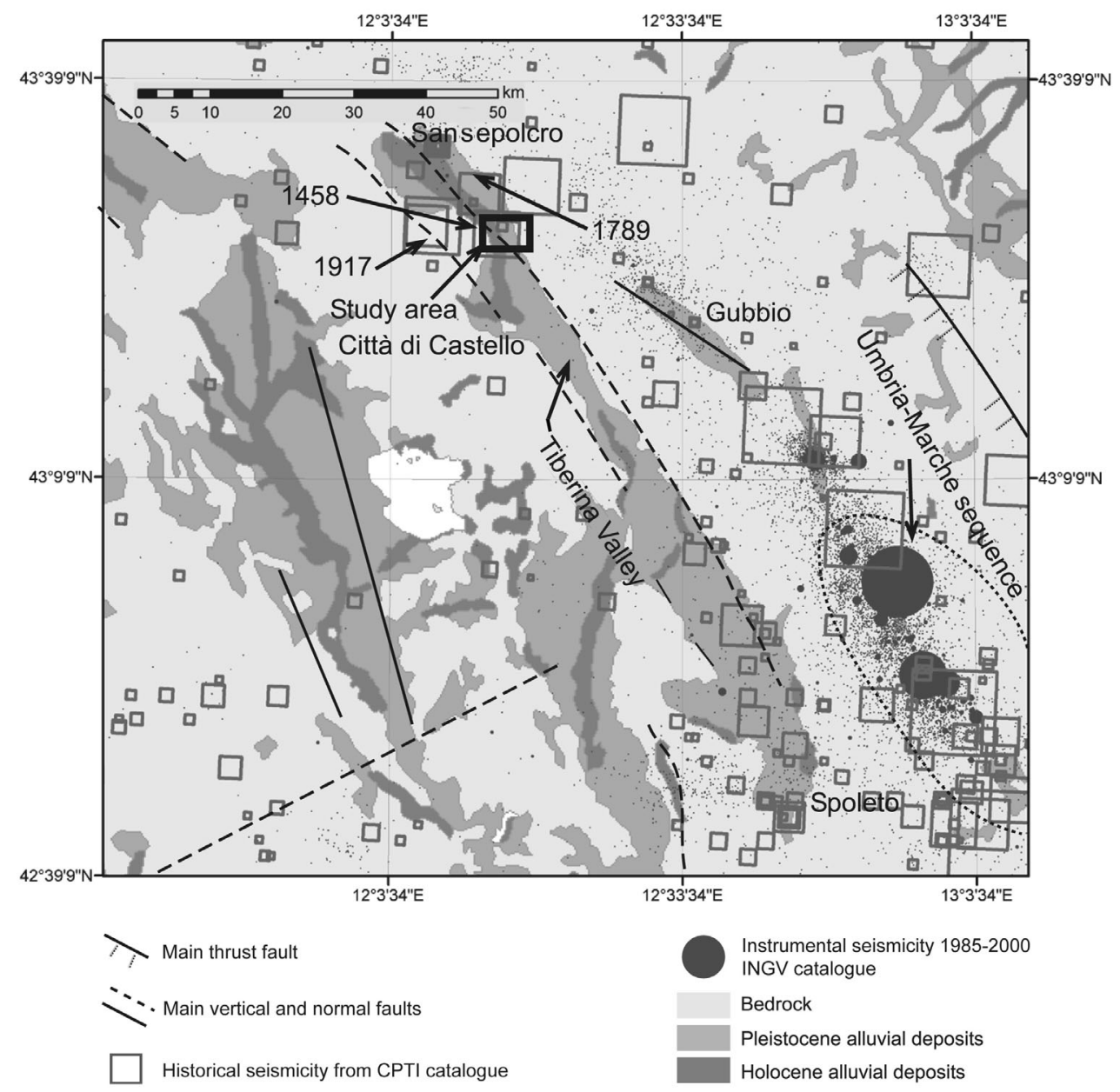

Fig. 1. Simplified geological and structural map of the investigated area. Historical and instrumental seismicity is also shown.

was chosen as a test site to compare different methodologies of ground motion simulation, including the effects of near surface geology. The site response experiment followed a passive seismic experiment aimed at studying the background seismicity at high resolution, in order to find the location and geometry of active faults that might generate moderate-to-strong earthquakes (Piccinini et al., 2003). In that experiment, a regional network of 27 stations operated in the surrounding area from October 2000 to May 2001 and located more than 2000 events; 4 of these stations were also maintained during this site response experiment to constrain the earthquake locations.

The Regione Umbria is affected by Plio-Quaternary extensional tectonics, which gives rise to continental basins. One of the most important amongst them is the Valtiberina Valley whose 
main branch extends from Sansepolcro, in the north, to Spoleto, in the south, including the Città di Castello Basin (fig. 1). The sedimentary sequence that fills this basin consists of Plio-Quaternary continental, fluvial and lacustrine deposits.

Città di Castello is the most important town of the northern part of the Valtiberina Valley. The urban settlement is characterised by a central area with buildings of historical and archi- tectural importance and a peripheral area with a dense concentration of private houses and facilities. The historical centre is built on Pleistocene and Holocene alluvial sediments; the bedrock of the basin is a «Marnoso-Arenacea» formation, Miocene pelites and sandstone (fig. 2a) (Boscherini et al., 2002).

Città di Castello was chosen as a test site for several reasons. Firstly, it is representative of both
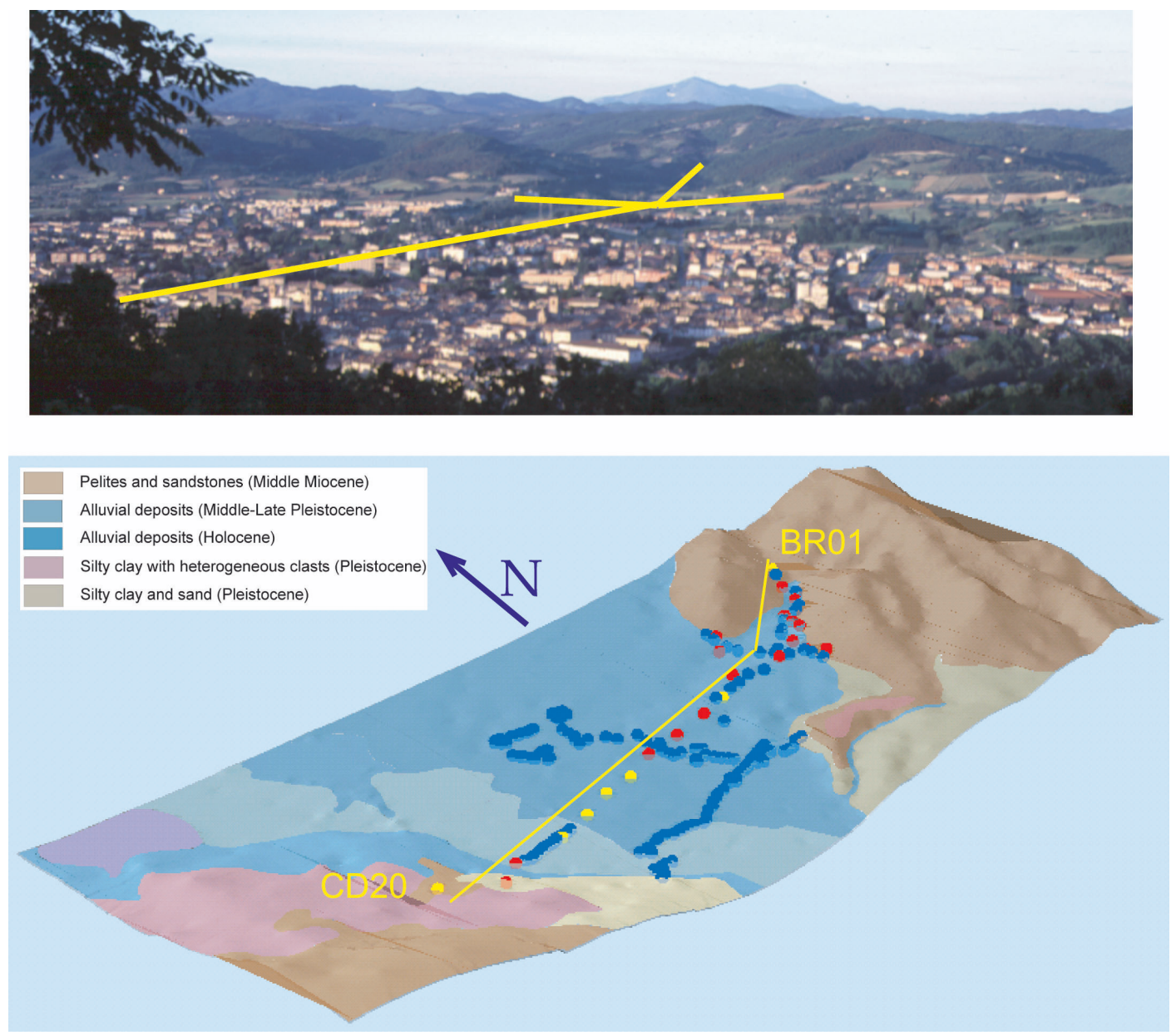

Fig. 2a. Top panel shows a panoramic view of Città di Castello town with the array position (yellow lines); note the high urbanization. Bottom panel shows topography and geology of the study area. Red and yellow dots are sites of the array stations; blue dots show noise measurements sites. The yellow line is the trace of the topographic profile in fig. $4 \mathrm{c}$. 
the typical urban situation and the geological setting of the towns in Central-Southern Italy. Secondly, the analysis of the last 20 years of seismicity data indicates that a low number of earthquakes with magnitude greater than 3.0 occurred in the area between Città di Castello and Gubbio. This area is very close (a few tens of kilometres) to the region affected by the Umbria-Marche earthquake sequence of 1997-1998 (Amato et al., 1998; Cattaneo et al., 2000; Deschamps et al., 2000). The historical catalogues (Monachesi and Stucchi, 1997; Gruppo di Lavoro CPTI, 1999) report a significant quake in the XV century (the Città di Castello April 26, 1458 earthquake with an IX MCS intensity) whose epicentral area is not clearly identified, an intensity VIII-IX earthquake in 1789 (located in Valtiberina) and a more recent event in 1917 (IX MCS intensity) (fig. 1). Finally, the sediment-filled valley of Città di Castello was chosen as a test site because it has been already investigated within a microzonation re- search project funded by the «Regione Umbria» (RU project) for the evaluation of site effects in town due to geological and morphological features (Boscherini et al., 2002; Checcucci et al., 2002; Crespellani et al., 2002; de Franco et al., 2002; Pergalani et al., 2002a). These studies provided detailed geological mapping of the bedrock units and alluvial lacustrine fillings, and the seismic wave velocity in the different formations using geotechnical and geophysical data.

\section{The GNDT project: a dense site response experiment}

The main goal of the experiment was to study the amplification pattern of ground motion and to investigate the geometry of the basin. The uniqueness of the $\mathrm{CDC}$ site response experiment is the very dense network used to study the variation of earthquake waveforms

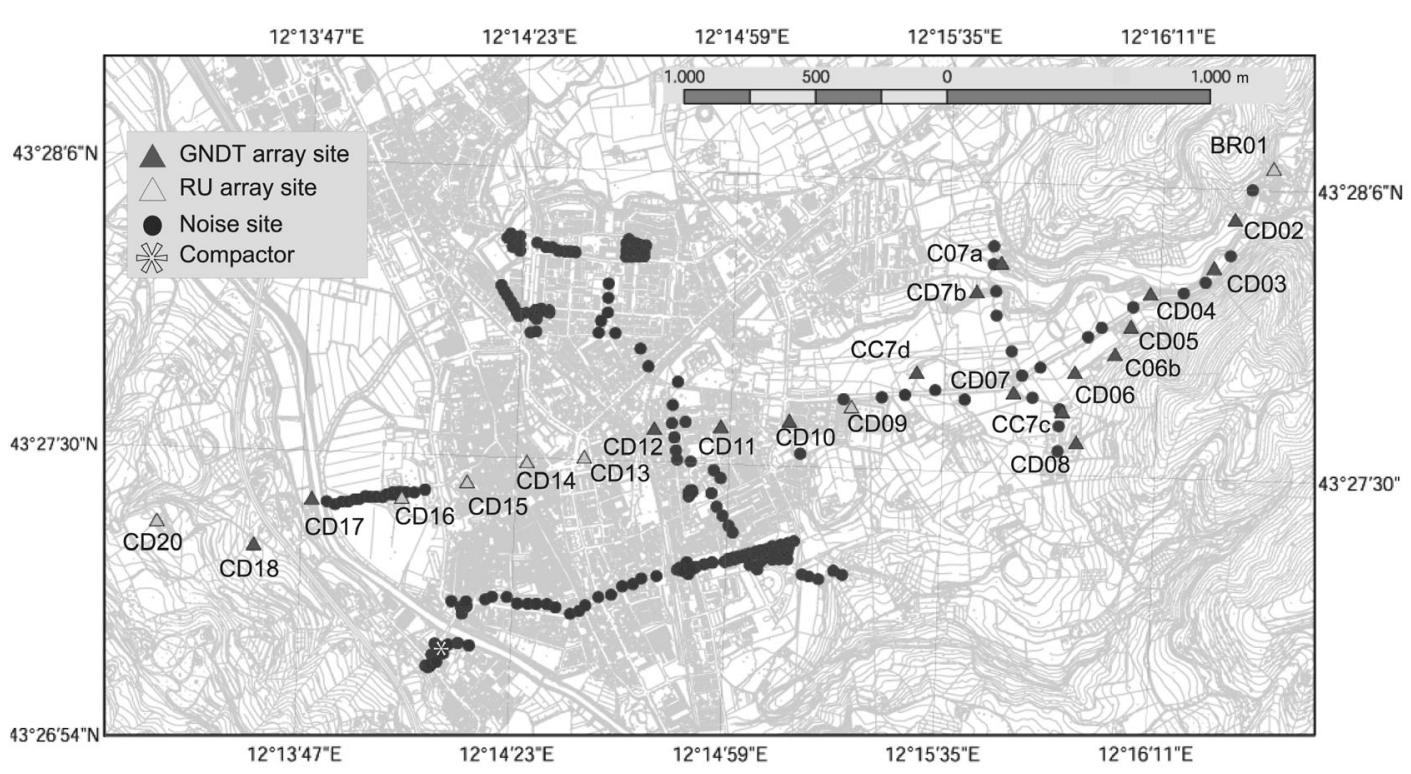

Fig. 2b. Station locations in the study area. Triangles show the sites of the array stations: the GNDT experiment ones are in dark gray while the Regione Umbria (RU) ones, re-occupied during the GNDT experiment, are in light gray. Dots show noise measurements sites. Star located the compactor device described in the text. 
across the valley (25 stations with inter-station distance of about $250 \mathrm{~m}$ ).

The acquisition lasted for 10 days in May 2001, and consisted of two linear arrays of closely spaced stations, deployed in a crosswise configuration, that recorded $32.5 \mathrm{~Gb}$ of continuous data (fig. 2a,b). One array of 20 stations was arranged along the WSW-ENE direction across the town of Città di Castello (seven of these sites had already been monitored in the Regione Umbria experiment, see fig. 2b), from the eastern bedrock (BR01) to the western edge (CD20). The second array of 5 sites was deployed along the NW-SE direction, orthogonal to the previous one. Bedrock sites BR01 and CD20 have been used as reference for the experiment. To prevent possible loss of data deriving from equipment failures, we doubled up the equipment at these reference sites.
In addition, several ambient noise measurements both in single station as well as in array configuration were performed spread over the area investigated, including the Tiber River, the town of Città di Castello and the western portion of the basin outside the town (fig. 2a,b).

Coordination among several Institutions (INGV, INOGS, IDPA and Dip.Te.Ris.) was one of the strengths of the experiment, allowing us to utilize many instruments for a site response experiment and to train and update researchers, technicians and students in installing and maintaining a temporary network for a seismic emergency. Lennartz (MarsLite, Mars88 and Le5800), Reftek (72A), Nanometrics (Orion) acquisition systems and Mark Products (L-4-3D $1 \mathrm{~Hz})$, Lennartz (LE3D $5 \mathrm{~s}$ and $1 \mathrm{~Hz}$ ) 3-component seismometers were deployed (table I), after performing a successful calibration test using a minibang gun.

Table I. The symbol (*) in the station code column indicates the sites in common with the Regione Umbria research project (April 2000 to December 2000). In Rec. mode column, C is for continuous recordings and T for trigger mode.

\begin{tabular}{|c|c|c|c|c|c|}
\hline Station code & Long. E & Lat. $\mathrm{N}$ & Digitizer & Sensor & Rec. mode \\
\hline BR01* & 12.27500 & 43.46910 & $\begin{array}{l}\text { Mars88 } \\
\text { Le5800 }\end{array}$ & $\begin{array}{l}\text { MarkL4-C } 1 \mathrm{~s} \\
\text { Lennartz } 5 \mathrm{~s}\end{array}$ & $\begin{array}{l}\mathrm{T} \\
\mathrm{C}\end{array}$ \\
\hline CD02 & 12.27325 & 43.46731 & Le5800 & Lennartz $5 \mathrm{~s}$ & $\mathrm{C}$ \\
\hline CD03 & 12.27233 & 43.46563 & Reftek 72A & Lennartz $5 \mathrm{~s}$ & $\mathrm{C}$ \\
\hline CD04 & 12.26938 & 43.46467 & Le5800 & Lennartz $5 \mathrm{~s}$ & $\mathrm{C}$ \\
\hline CD05 & 12.26900 & 43.46352 & Mars88 & Mark L4C $1 \mathrm{~s}$ & $\mathrm{~T}$ \\
\hline CD06 & 12.26595 & 43.46188 & Reftek 72A & Lennartz 5 s & $\mathrm{C}$ \\
\hline $\mathrm{C} 06 \mathrm{~b}$ & 12.26782 & 43.46254 & Le5800 & Lennartz $5 \mathrm{~s}$ & $\mathrm{C}$ \\
\hline CD07 & 12.26309 & 43.46112 & Reftek 72A & Lennartz $5 \mathrm{~s}$ & $\mathrm{C}$ \\
\hline $\mathrm{C} 07 \mathrm{a}$ & 12.26233 & 43.46558 & Le5800 & Lennartz $5 \mathrm{~s}$ & $\mathrm{C}$ \\
\hline CD7b & 12.26121 & 43.46456 & Reftek 72A & Lennartz $5 \mathrm{~s}$ & $\mathrm{C}$ \\
\hline $\mathrm{CC} 7 \mathrm{c}$ & 12.26540 & 43.46054 & Mars Lite & Lennartz $5 \mathrm{~s}$ & $\mathrm{C}$ \\
\hline CD7d & 12.25851 & 43.46171 & Mars Lite & Lennartz $5 \mathrm{~s}$ & $\mathrm{C}$ \\
\hline CD08 & 12.26611 & 43.45947 & Mars Lite & Lennartz $5 \mathrm{~s}$ & $\mathrm{C}$ \\
\hline CD09* & 12.25549 & 43.46047 & Mars88 & Mark L4C $1 \mathrm{~s}$ & $\mathrm{~T}$ \\
\hline CD10 & 12.25260 & 43.45990 & Orion & Lennartz 5 s & $\mathrm{C}$ \\
\hline CD11 & 12.24939 & 43.45963 & Mars88 & Mark L4C $1 \mathrm{~s}$ & $\mathrm{~T}$ \\
\hline CD12 & 12.24626 & 43.45949 & Le5800 & Lennartz 5 s & $\mathrm{C}$ \\
\hline CD13* & 12.24301 & 43.45843 & Orion & Lennartz $1 \mathrm{~s}$ & $\mathrm{C}$ \\
\hline CD14* & 12.24033 & 43.45820 & Reftek & Lennartz $5 \mathrm{~s}$ & $\mathrm{C}$ \\
\hline CD15* & 12.23755 & 43.45745 & Mars88 & Mark L4C $1 \mathrm{~s}$ & $\mathrm{~T}$ \\
\hline CD16* & 12.23451 & 43.45685 & Orion & Lennartz 1 s & $\mathrm{C}$ \\
\hline CD17 & 12.23029 & 43.45671 & Le5800 & Lennartz $5 \mathrm{~s}$ & $\mathrm{C}$ \\
\hline CD18 & 12.22764 & 43.45508 & Reftek & Lennartz $5 \mathrm{~s}$ & $\mathrm{C}$ \\
\hline \multirow[t]{2}{*}{ CD20* } & 12.22305 & 43.45580 & Reftek & Lennartz $5 \mathrm{~s}$ & $\mathrm{C}$ \\
\hline & & & Mars88 & Mark L4C $1 \mathrm{~s}$ & $\mathrm{~T}$ \\
\hline
\end{tabular}


About 70 earthquakes were recorded during the 10 days of deployment, generally of low magnitude or regional events.

\section{Earthquakes locations}

Looking at data coming from the same seismic area, it is quite common to find seismograms sharing all the major features and, in some cases, showing almost identical waveforms. A pair of such similar events is defined as a doublet. Geller and Mueller (1980) found that earthquakes with such characteristics are caused by very similar focal mechanism and their hypocenters lie within one quarter of the shortest wavelength to which similarity holds. We take advantage of these characteristics adopting a waveform similarity approach (Cattaneo et al., 1999) for a better location of 17 earthquakes (table II). Four stations of the regional network operating in the surrounding area between October 2000 and May 2001 were maintained during the site effect experiment (triangles in fig. 3). The arrival times differences of $P$ - and $S$-phases at these stations were compared with those of the previously located events, in order to disclose potential «twin earthquakes» (fig. 3 ). Between them we chose those that maximize the cross-correlation function with the events also recorded by the transect stations, using the doublet analysis techniques (Poupinet et al., 1985; Augliera et al., 1995). The location of the most similar earthquake of the regional network was then adopted as location for the transect event. Using this approach we could locate most of the well-recorded events; only 6 earthquakes with good signal-to-noise ratio did not have a corresponding «twin» earthquake. We located them using the arrival times picked at both the stations of the experiment and of the INGV national network (table II).

\section{Amplitude variation and bedrock geometry reconstruction}

Figure 4a displays the EW component of a shallow earthquake $\left(M_{L}=1.9\right)$ recorded by the transect stations along the WSW-ENE profile. The large ground motion amplification of the $S$ - wave arrivals in the central part of the valley, nearly in the centre of the town, is about 7 times the bedrock recording. The waveforms recorded at CD17 and CD18 are strongly affected by the vicinity of the Tiber River and a main road with heavy traffic. In addition, in spite of the proximity of the stations (about $250 \mathrm{~m}$ ) there is a relative delay in arrival times at the stations located into the basin (fig. 4b). We can use these relative delays of the $S$ arrival times to make a rough estimate of the bedrock depth for the Città di Castello Basin.

The bedrock is composed of siliciclastic deposits («Formazione Marnoso Arenacea») of Middle-Late Miocene age (Bonini, 1998) with $P$-waves velocities, $V_{p_{\text {Bedrock }}}$ of $2000-2600 \mathrm{~m} / \mathrm{s}$ (average $2300 \mathrm{~m} / \mathrm{s}$ ) and with $S$-waves velocities, $V_{s_{\text {Bedrock }}}$, of $1000-1200 \mathrm{~m} / \mathrm{s}$ (average $1100 \mathrm{~m} / \mathrm{s}$ ) (Checcucci et al., 2002). The geological survey of Regione Umbria provided borehole logs for the Città di Castello area. Generally the wells, with a mean depth of tens of meters, do not reach the bedrock. However, the bedrock was found at a depth of $144 \mathrm{~m}$ at one of our sites (CD16).

We picked the $S$ phases at all the available stations for 3 of the events in table II, localized east of the transect. We considered only the arrivals with a good signal-to-noise ratio and evaluated the delays relative to BR01; we gave an estimate of our picking error and made an average of the delays if more than one picking was available at the same station ( $S$-wave delays and their errors are in table III and fig. 4b). We assume that the difference in arrival time between BR01 and CD20 is only due to the propagation of the wave front in the bedrock (fig. 4b); these two arrival times at the extremities of the transect allowed us to evaluate, at all the stations, $S$-wave theoretical delays due to the wave propagation in a homogeneous medium ( $S$-wave theoretical delays table III and fig. $4 \mathrm{~b})$. We first computed the $V_{s}$ value of the sediments below CD16. The sediment thickness is known only at this site, where the difference between the observed and the theoretical arrival time is $0.406 \mathrm{~s}$. We assign this difference to sediment coverage. In this computation, we also consider a topographic correction related to the difference in altitude between BR01 and CD16; for the station CD16 this correction is $0.060 \mathrm{~s}$ 
Table II. Earthquakes location.

\begin{tabular}{|c|c|c|c|c|c|}
\hline Analysis & $\begin{array}{l}\text { Earthquake } \\
\text { origin time }\end{array}$ & $\begin{array}{l}\text { Hypocentral coordinates } \\
\text { site resp. earth. }\end{array}$ & $M_{L}$ & $\begin{array}{l}\text { Twin earth. } \\
\text { origin time }\end{array}$ & $\begin{array}{l}\text { Hypocentral coordinates } \\
\text { twin earth. }\end{array}$ \\
\hline & $\begin{array}{l}2001.05 .15 \\
18: 47: 18.84\end{array}$ & $\begin{array}{c}43 \mathrm{~N} 22.72 \text { 12E } 48.16 \\
\mathrm{~km} 9.5\end{array}$ & 1.5 & $\begin{array}{l}2001.03 .27 \\
02: 33: 53.83\end{array}$ & $\begin{array}{c}43 \mathrm{~N} 24.03 \text { 12E47.34 } \\
\mathrm{km} 10\end{array}$ \\
\hline & $\begin{array}{c}2001.05 .18 \\
00: 37: 30.09 \\
\end{array}$ & $\begin{array}{c}43 \mathrm{~N} 27.0012 \mathrm{E} 30.40 \\
\mathrm{~km} 2.5\end{array}$ & 0.9 & $\begin{array}{c}2001.05 .07 \\
22: 19: 51.99\end{array}$ & $\begin{array}{c}43 \mathrm{~N} 27.02 \text { 12E30.33 } \\
\mathrm{km} 2.4\end{array}$ \\
\hline & $\begin{array}{l}\text { 2001.05.18 } \\
06: 56: 23.03\end{array}$ & $\begin{array}{c}\text { 43N24.74 12E28.55 } \\
\text { km } 3.4\end{array}$ & 1.2 & $\begin{array}{l}\text { 2001.11.28 } \\
11: 20: 09.93\end{array}$ & $\begin{array}{c}\text { 43N25.05 12E } 28.03 \\
\mathrm{~km} 3.7\end{array}$ \\
\hline SSR* & $\begin{array}{l}2001.05 .18 \\
07: 1913.12 \\
\end{array}$ & $\begin{array}{c}43 \mathrm{~N} 36.16 \text { 12E34.65 } \\
\text { km } 12\end{array}$ & 1.9 & No twin & \\
\hline \multirow[t]{2}{*}{ SSR } & $\begin{array}{l}2001.05 .18 \\
20: 46: 18.88\end{array}$ & $\begin{array}{c}43 \mathrm{~N} 27.02 \text { 12E26.49 } \\
\mathrm{km} 2.5\end{array}$ & 1.9 & $\begin{array}{l}2001.03 .28 \\
04: 07: 41.27\end{array}$ & $\begin{array}{c}43 \mathrm{~N} 26.54 \text { 12E } 26.62 \\
\mathrm{~km} 2.5\end{array}$ \\
\hline & $\begin{array}{l}2001.05 .18 \\
21: 10: 51.82\end{array}$ & $\begin{array}{c}\text { 43N22.62 12E31.76 } \\
\text { km 2.9 }\end{array}$ & 1.1 & $\begin{array}{l}\text { 2001.05.10 } \\
12: 04: 33.66\end{array}$ & $\begin{array}{c}\text { 43N22.84 12E31.69 } \\
\text { km 2.7 }\end{array}$ \\
\hline SSR & $\begin{array}{l}2001.05 .18 \\
23: 02: 8.54\end{array}$ & $\begin{array}{c}42 \mathrm{~N} 50.9312 \mathrm{E} 32.94 \\
\mathrm{~km} 10\end{array}$ & 3.2 & No twin & \\
\hline SSR & $\begin{array}{l}2001.05 .19 \\
01: 15: 24.63\end{array}$ & $\begin{array}{c}43 \mathrm{~N} 22.49 \text { 12E } 31.78 \\
\mathrm{~km} 2.7\end{array}$ & 0.9 & $\begin{array}{l}2001.05 .10 \\
01: 24: 33.66\end{array}$ & $\begin{array}{c}\text { 43N22.84 12E31.69 } \\
\text { km } 2.7\end{array}$ \\
\hline \multirow[t]{3}{*}{ SSR } & $\begin{array}{l}2001.05 .19 \\
02: 14: 10.57\end{array}$ & $\begin{array}{c}\text { 43N23.31 12E28.05 } \\
\text { km } 1.0\end{array}$ & 1.3 & $\begin{array}{l}2001.05 .04 \\
15: 36: 41.62\end{array}$ & $\begin{array}{c}\text { 43N23.38 12E29.34 } \\
\text { km 2.4 }\end{array}$ \\
\hline & $\begin{array}{c}2001.05 .19 \\
05: 32: 28.82 \\
\end{array}$ & $\begin{array}{c}43 \mathrm{~N} 22.08 \text { 12E31.69 } \\
\mathrm{km} 1.6\end{array}$ & 1.4 & $\begin{array}{c}2001.05 .10 \\
01: 24: 33.66\end{array}$ & $\begin{array}{c}43 \mathrm{~N} 22.8412 \mathrm{E} 31.69 \\
\mathrm{~km} 2.7\end{array}$ \\
\hline & $\begin{array}{l}2001.05 .19 \\
23: 45: 5.44\end{array}$ & $\begin{array}{c}43 \mathrm{~N} 24.53 \text { 12E29.83 } \\
\mathrm{km} 3.3\end{array}$ & 0.8 & $\begin{array}{l}2001.02 .16 \\
16: 24: 37.5\end{array}$ & $\begin{array}{c}\text { 43N25.70 12E30.76 } \\
\text { km } 3.6\end{array}$ \\
\hline \multirow[t]{3}{*}{ SSR } & $\begin{array}{l}\text { 2001.05.20 } \\
\text { 05:07:50.44 }\end{array}$ & $\begin{array}{c}\text { 43N51.45 12E32.05 } \\
\text { km } 1.7\end{array}$ & 3.0 & No twin & \\
\hline & $\begin{array}{c}2001.05 .20 \\
23: 43: 38.44\end{array}$ & $\begin{array}{c}43 \mathrm{~N} 29.63 \text { 12E25.39 } \\
\mathrm{km} 2.6\end{array}$ & 0.7 & $\begin{array}{c}2001.02 .03 \\
11: 16: 46.77 \\
\end{array}$ & $\begin{array}{c}43 \mathrm{~N} 28.68 \text { 12E25.71 } \\
\mathrm{km} 5.7\end{array}$ \\
\hline & $\begin{array}{l}\text { 2001.05.21 } \\
00: 40: 3.25 \\
\end{array}$ & $\begin{array}{c}43 \mathrm{~N} 24.93 \text { 12E } 30.05 \\
\mathrm{~km} 3.7\end{array}$ & 1.5 & $\begin{array}{c}2001.04 .21 \\
01: 24: 02.08 \\
\end{array}$ & $\begin{array}{c}\text { 43N25.17 12E29.94 } \\
\text { km } 3.7\end{array}$ \\
\hline $\mathrm{SSR}^{*}$ & $\begin{array}{c}2001.05 .22 \\
02: 50: 52.85 \\
\end{array}$ & $\begin{array}{c}43 \mathrm{~N} 25.93 \text { 12E30.36 } \\
\mathrm{km} 4.6\end{array}$ & 1.5 & $\begin{array}{l}\text { 2001.04.20 } \\
\text { 20:56:45.51 }\end{array}$ & $\begin{array}{c}\text { 43N25.56 12E29.57 } \\
\mathrm{km} 4.4\end{array}$ \\
\hline \multirow[t]{4}{*}{ SSR } & $\begin{array}{c}2001.05 .22 \\
03: 28: 49.78 \\
\end{array}$ & $\begin{array}{c}\text { 43N4.38 12E53.75 } \\
\text { km } 0.8 \\
\end{array}$ & 2.9 & No twin & \\
\hline & $\begin{array}{l}2001.05 .22 \\
14: 02: 17.27 \\
\end{array}$ & $\begin{array}{c}\text { 43N26.07 12E27.43 } \\
\text { km 3.8 }\end{array}$ & 1.2 & $\begin{array}{c}2001.04 .17 \\
05: 52: 47.96 \\
\end{array}$ & $\begin{array}{c}43 \mathrm{~N} 23.81 \text { 12E28.96 } \\
\mathrm{km} 2.8 \\
\end{array}$ \\
\hline & $\begin{array}{c}2001.05 .22 \\
14: 22: 22.61 \\
\end{array}$ & $\begin{array}{c}\text { 43N21.82 } 12 \mathrm{E} 32.54 \\
\mathrm{~km} 1.9\end{array}$ & 1.3 & $\begin{array}{l}2001.05 .06 \\
00: 14: 07.82 \\
\end{array}$ & $\begin{array}{c}\text { 43N22.25 12E32.57 } \\
\text { km } 2.5\end{array}$ \\
\hline & $\begin{array}{c}2001.05 .22 \\
14: 41: 24.71 \\
\end{array}$ & $\begin{array}{c}43 \mathrm{~N} 19.79 \text { 12E33.19 } \\
\mathrm{km} 2.0\end{array}$ & 1.4 & $\begin{array}{l}\text { 2001.04.09 } \\
13: 30: 22.51\end{array}$ & $\begin{array}{c}\text { 43N19.13 12E33.44 } \\
\text { km } 4.5\end{array}$ \\
\hline \multirow[t]{2}{*}{ SSR } & $\begin{array}{c}2001.05 .22 \\
22: 35: 37.16\end{array}$ & $\begin{array}{c}\text { 43N35.31 12E18.62 } \\
\text { km } 4.6\end{array}$ & 1.7 & No twin & \\
\hline & $\begin{array}{l}2001.05 .23 \\
15: 11: 42.06\end{array}$ & $\begin{array}{c}\text { 43N23.41 12E29.17 } \\
\text { km 2.4 }\end{array}$ & 1.7 & $\begin{array}{l}2001.04 .12 \\
03: 14: 51.89\end{array}$ & $\begin{array}{c}43 \mathrm{~N} 23.59 \text { 12E29.38 } \\
\mathrm{km} 2.9\end{array}$ \\
\hline \multirow[t]{2}{*}{ SSR* } & $\begin{array}{l}\text { 2001.05.23 } \\
\text { 19:35:51.51 }\end{array}$ & $\begin{array}{c}\text { 43N27.83 12E22.29 } \\
\mathrm{km} 3.0\end{array}$ & 0.9 & No twin & \\
\hline & $\begin{array}{l}\text { 2001.05.24 } \\
13: 12: 28.1\end{array}$ & $\begin{array}{c}\text { 43N22.59 12E29.91 } \\
\text { km } 2.1\end{array}$ & 1.0 & $\begin{array}{l}\text { 2001.02.02 } \\
01: 49: 01.21\end{array}$ & $\begin{array}{c}\text { 43N23.13 12E29.37 } \\
\text { km } 2.3\end{array}$ \\
\hline
\end{tabular}

(*) earthquakes used for depth reconstruction; (SSR) earthquakes used in SSR analysis. 


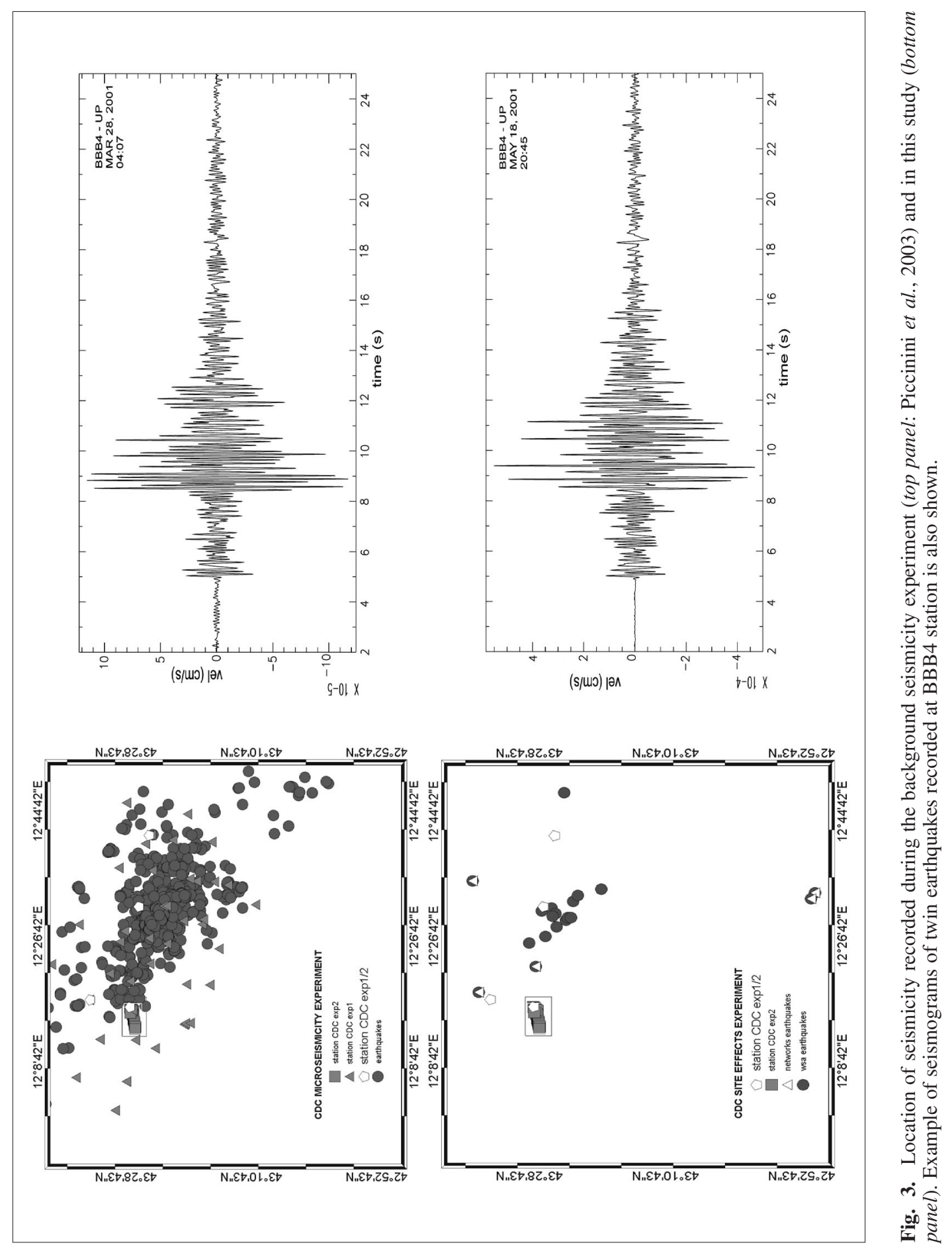




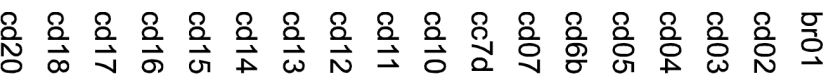

(a)

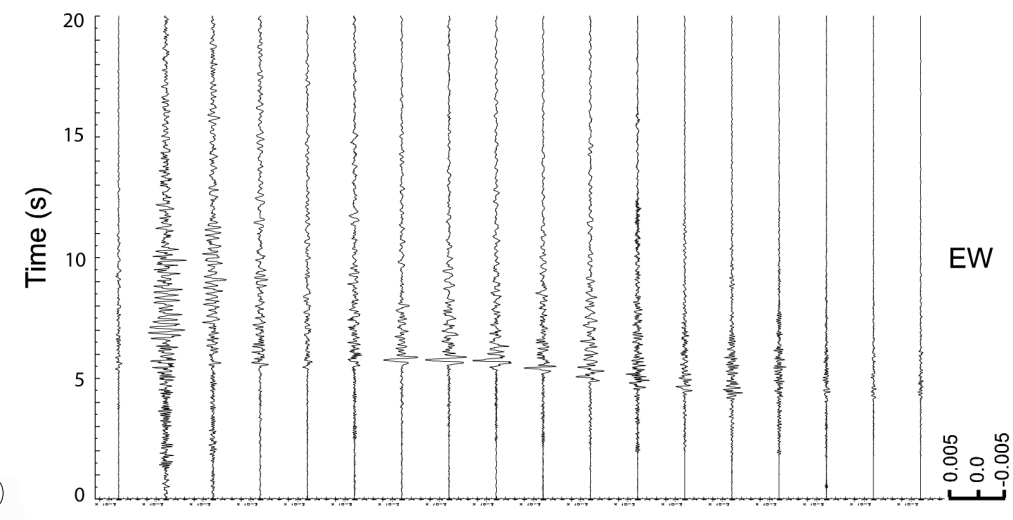

Vel $(\mathrm{cm} / \mathrm{s})$

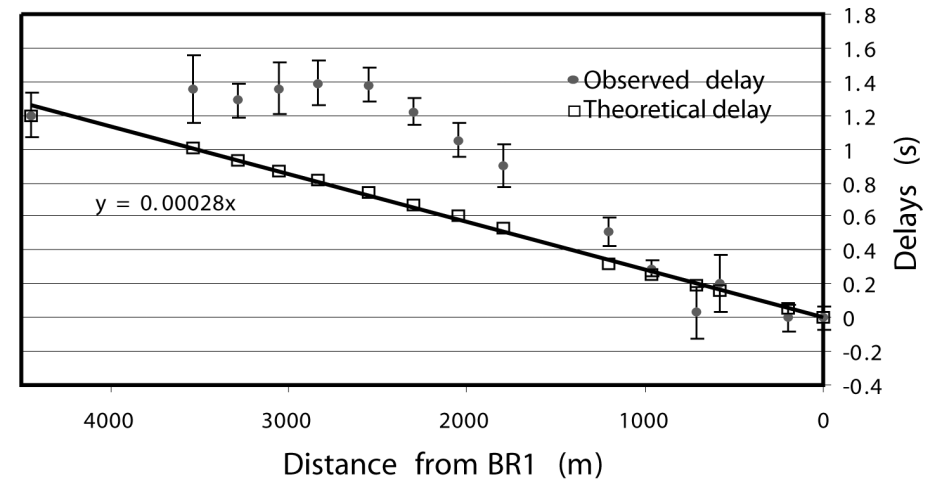

(b)

Distance from BR1 (m)

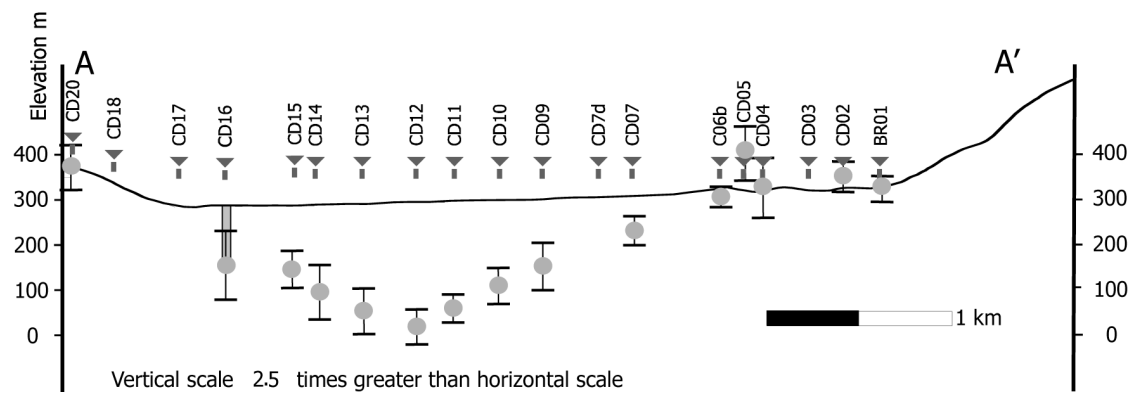

Fig. 4a-c. a) EW component of a shallow earthquake $\left(M_{L}=1.9\right)$ recorded by the transect stations. Note that ground motion amplitudes are significantly larger in the central-western sites. b) Observed and theoretical delay time of $S$ wave arrival with respect to BR01. We picked 3 events located $\mathrm{E}$ of the array and calculate average delay times and average reading errors (error bars). c) EW profile along the transect, the grey points represent the computed depth of the bedrock and errors are propagated from reading errors above. The borehole underneath CD16 is also shown. 
Paola Bordoni et al.

Table III. $P$ - and $S$-wave arrival times relative to BR01 and bedrock depth.

\begin{tabular}{cccccc}
\hline \hline Station & $\begin{array}{c}S \text {-wave } \\
\text { obs. delays }\end{array}$ & $\begin{array}{c}\text { Erros on } \\
S \text {-wave obs. (s) }\end{array}$ & $\begin{array}{c}S \text {-wave } \\
\text { teo. delays }(*)\end{array}$ & $\Delta$ RitS & $\begin{array}{c}\text { Bedrock depth } \\
\text { (m below surface) }\end{array}$ \\
\hline BR01 & 0.00 & 0.07 & 0.000 & 0.000 & 0 \\
CD02 & 0.00 & 0.08 & 0.054 & -0.054 & -22 \\
CD04 & 0.20 & 0.17 & 0.158 & 0.042 & 17 \\
CD05 & 0.03 & 0.15 & 0.194 & -0.164 & -66 \\
CD06 & 0.29 & 0.05 & 0.261 & 0.029 & 12 \\
CD07 & 0.51 & 0.08 & 0.324 & 0.186 & 76 \\
CD09 & 0.90 & 0.13 & 0.536 & 0.364 & 168 \\
CD10 & 1.05 & 0.10 & 0.605 & 0.445 & 181 \\
CD11 & 1.22 & 0.08 & 0.671 & 0.549 & 223 \\
CD12 & 1.38 & 0.10 & 0.739 & 0.641 & 260 \\
CD13 & 1.39 & 0.13 & 0.815 & 0.575 & 233 \\
CD14 & 1.36 & 0.15 & 0.874 & 0.486 & 197 \\
CD15 & 1.29 & 0.10 & 0.937 & 0.353 & 143 \\
CD16 & 1.36 & 0.20 & 1.004 & 0.356 & 144 \\
CD20 & 1.20 & 0.13 & 1.200 & 0.000 & 0 \\
\hline
\end{tabular}

(*) Topographic correction is included.

resulting in a $\Delta$ rit $S=0.346$. So we can obtain the average $S$-wave velocity of the sediments by simply applying the following formula:

$$
\Delta \operatorname{rit} S=H_{\text {Bedrock }} \cdot\left(1 / V_{S_{\text {sed }}}-1 / V_{S_{\text {Beedock }}}\right)
$$

The $V_{s}$ value found for the sediments $\left(V s_{\text {sed }}\right)$ is about $300 \mathrm{~m} / \mathrm{s}$.

Once we know the $V s_{\text {sed }}$ we can estimate the bedrock depth, $H_{\text {Bedrock, }}$, below each station (fig. $4 \mathrm{c}$; table III). Errors on pickings are propagated as errors on depth in fig. $4 c$. We found a maximum depth of about $260 \mathrm{~m}$ to the left side of the Tiber River below CD12, which is nearly in the centre of the town. The depth of the bedrock does not seem to have abrupt changes but smoothly emerges toward the two edges of the valley. The estimated $V s_{\text {sed }}$ is comparable to the value published in Crespellani et al. (2002).

\section{Spectral analysis}

\subsection{Urban noise}

First of all, we evaluated the noise level at each site: indeed the high level of noise represents one of the major difficulties for seismo-
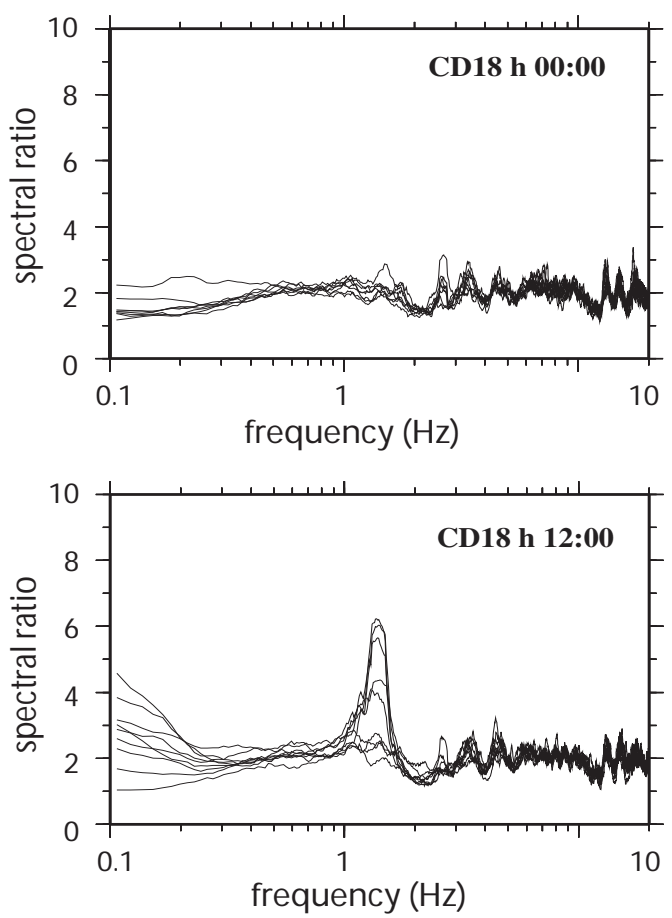

Fig. 5. Example of $H / V$ spectral ratios of noise recordings at $\mathrm{CD} 18$. We show the time windows recorded around midnight and noon for 10 days. 
logical surveys in urban areas. We observed an amplitude difference of more than a factor 2 between seismic noise recorded during day and night $(2.5 \mu / \mathrm{s}$ during the day, $1.0 \mu / \mathrm{s}$ during the night). In fig. 5 we report the analysis per-
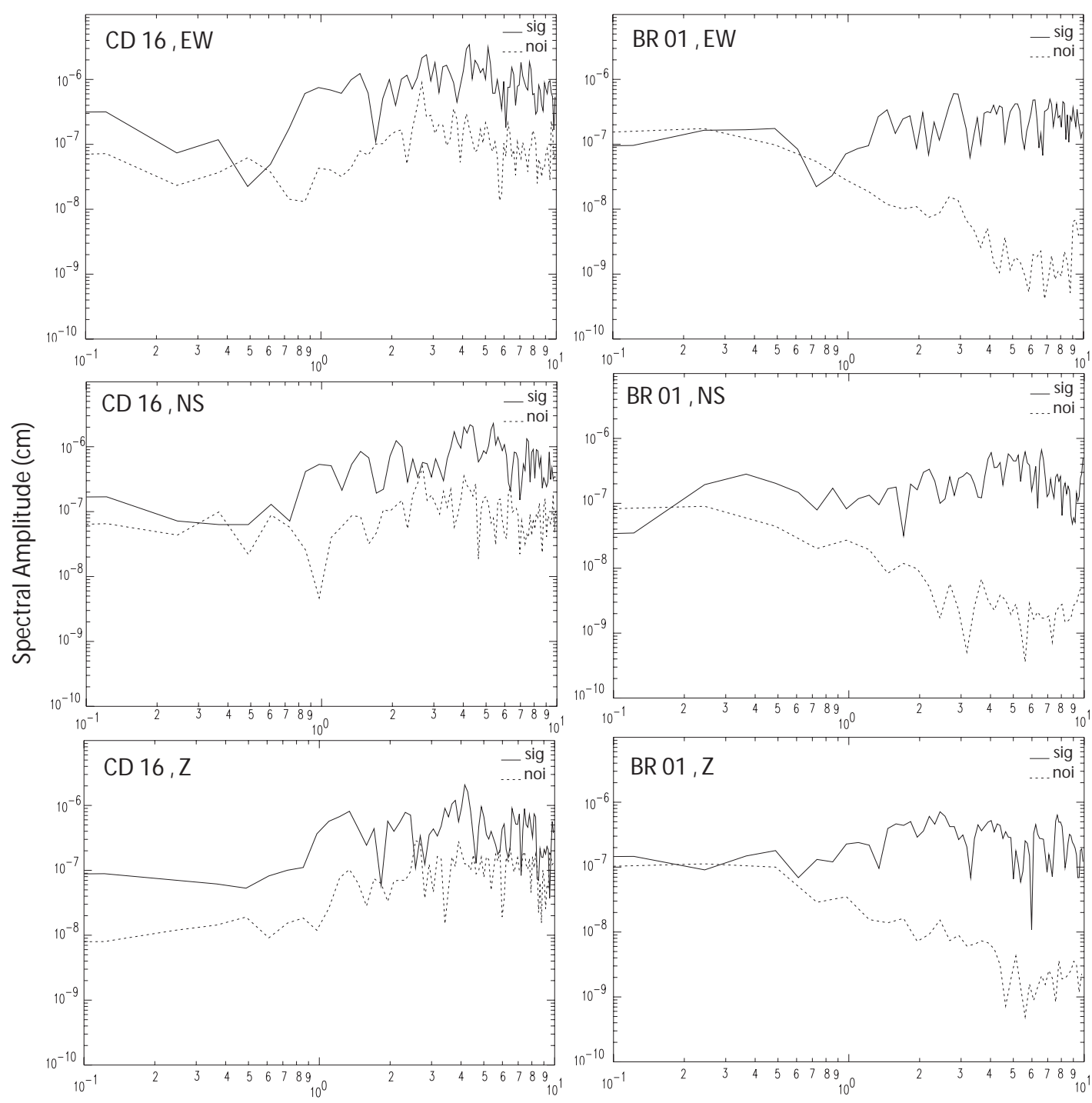

\section{Frequency $(\mathrm{Hz})$}

Fig. 6. Spectra of $S$-wave signal and pre-event noise of the 3 components of one of the analyzed earthquake at stations BR01 and CD16. 
h). We compute the spectral ratio of the horizontal versus vertical component of the signals with the so-called Nakamura technique (Nogoshi and Igarashi, 1970, 1971; Nakamura, 1989). We use a moving window of $40 \mathrm{~s}$ with a smoothing factor of $0.2 \mathrm{~Hz}$. The analysis performed exhibits a pronounced peak at $1.6 \mathrm{~Hz}$ in the daily recordings. Because this peak is completely absent during the night and holidays, we can exclude any possible link between this peak and structural condition of the basin. In fact, we found that this $1.6 \mathrm{~Hz}$ disturbance is produced by a compactor device located in a waste disposal site (fig. 2b). This noise analysis gave us important information about the limits of using earthquakes recorded inside the basin: we could only select events recorded during the night and made an accurate signal-to-oise analysis accepting spectral ratios only in the frequency band where the signal-to-noise ratio exceeds a threshold of 3 (fig. 6).

\subsection{Earthquake standard spectral ratios}

In this study we analyzed 10 earthquakes from the 19 stations along the EW transect. We applied the conventional spectral ratio technique (Borcherdt, 1970) to the two horizontal components separately to identify the frequency bands where amplification occurs. BR01, installed on a sandstone outcrop (bedrock), has been chosen as the reference site. We selected $S$-wave windows of 5-13 s using a $10 \%$ cosine taper. We then computed the Fourier transform and smoothed it with a mean operator of 0.3 Hz. Finally, the spectral ratios were computed from the conditioned spectra and averaged using 3 to 9 events for each station. In fig. 7 we show the standard deviation about the geometric mean in the frequency band $1-10 \mathrm{~Hz}$, where the $S$-wave signal exceeds a threshold of 3 in

Fig. 7. Standard deviation about the geometric mean amplification of the NS and EW components. Stations across the valley are ordered from east, above, to west, below.

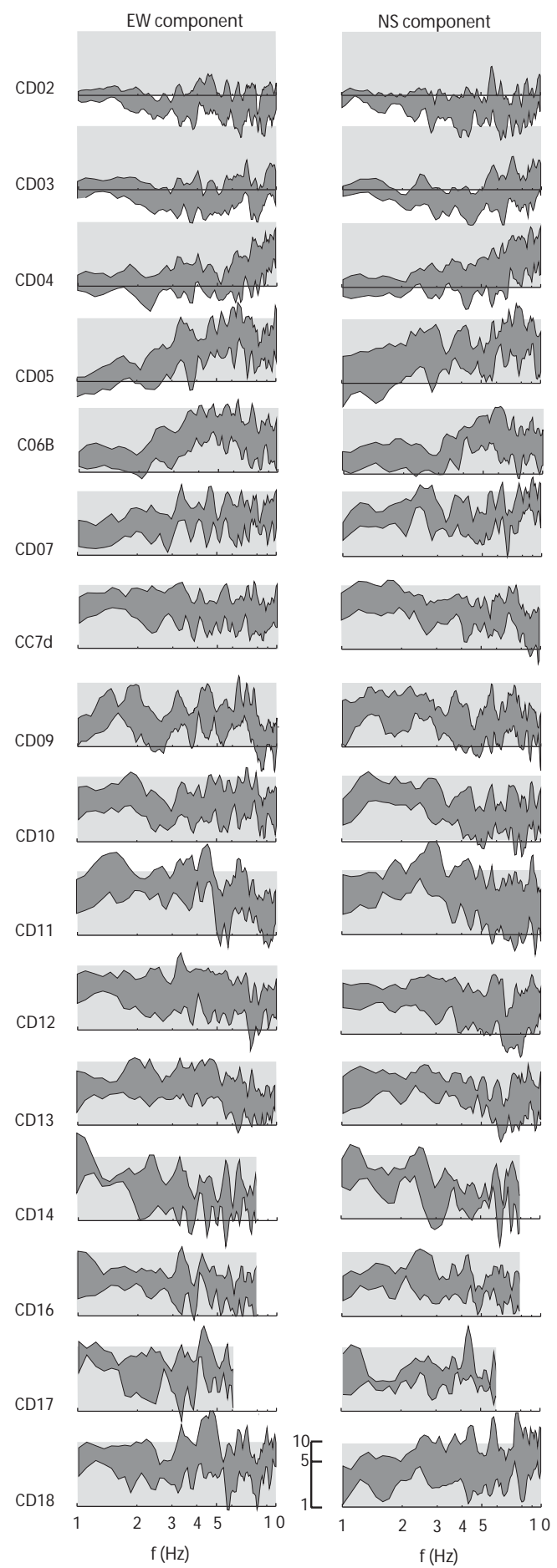


the signal-to-noise ratio (stations CD14, CD16 and CD17 are limited to $1-8 \mathrm{~Hz}, 1-8 \mathrm{~Hz}$ and 1$6 \mathrm{~Hz}$ respectively). The limited range of frequencies is due to the low-magnitude of the analyzed events and to the high noise level of the urbanized area.

The $S$-wave spectral ratios at the eastern stations (CD02 and CD03) are flat, whereas at CD04 frequencies higher than $8 \mathrm{~Hz}$ are amplified and CD05 and C06B show amplification in the frequency band $3-10 \mathrm{~Hz}$. Starting from CD07 we enter the basin (see figs. $2 b$ and $4 c$ ), and all the stations show several amplification peaks in the entire frequency band (1-10 Hz), with amplification factor reaching values up to 9. The highest values of amplification at frequency below $2 \mathrm{~Hz}$ are found between stations CD11 and CD14. Stations CD17 and CD18 have large amplification values also at high frequencies probably because of the presence of thin Holocene sediments of the Tiber River. In general, the NS and EW components show a slightly different behaviour and a high variability of the standard deviations. These features can be related to lateral variation of the geological structure of the basin; indeed the geometry of bedrock outcrops and the nature of the alluvial deposits are indicative of quite a complicated 3D structure that contributes to produce differences in spectral ratios of earthquakes approaching a station even from slightly different azimuths (Field, 1996; de Franco et al., 2002; Cultrera et al., 2003). The small number of events analyzed may also play a role in the high variability of standard deviation.

The availability of stratigraphy and geotechnical information ( $\mathrm{S}$ velocity values) at $\mathrm{CD} 16$ encourages us to check the empirical site response estimates provided by ground motion recordings with those resulting from simple theoretical calculations. We compute the 1D Horizontal Response (HR) of the shallow layers by means of the Haskell-Thompson method (Thompson, 1950; Haskell, 1953; Kennet and Kerry, 1979). The computation was done for $\mathrm{SH}$ waves with an incident angle of $15^{\circ}$ using the velocity model and the $Q$ value reported in table IV. In fig. 8 we show the theoretical response for CD16 site as well as the average spectral ratio of the two components. The fundamental resonant
Table IV. Velocity model for CD16.

\begin{tabular}{lccc}
\hline \hline CD16 & Thickness $(\mathrm{m})$ & $V_{s}(\mathrm{~km} / \mathrm{s})$ & $Q$ \\
\hline $\begin{array}{l}\text { Alluvial Holocene } \\
\text { deposits }\end{array}$ & 8 & 0.27 & 20 \\
$\begin{array}{l}\text { Alluvial Pleistocene } \\
\text { deposits }\end{array}$ & 136 & 0.30 & 50 \\
Bedrock & & 1.10 & 1000 \\
\hline
\end{tabular}

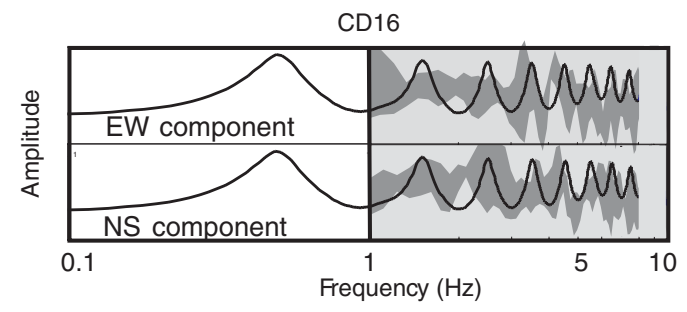

Fig. 8. Theoretical 1D transfer function at CD16 (Haskell-Thompson method) for the stratigraphy of table IV, compared to earthquakes spectral ratios.

peak of the model is at $0.5 \mathrm{~Hz}$ where the spectral ratios are not reliable; above $1 \mathrm{~Hz}$ the $\mathrm{HR}$ is comparable to the empirical earthquake data in amplitude, but peaks and troughs do not match. The mismatch may be the result of the quite complicated 3D geological structure.

To pursue the main aim of the GNDT project «Development and comparison among methodologies for the evaluation of seismic hazard in seismogenic areas: application to the Central and Southern Apennines», we tried to quantify the influence of the evaluated relative site response on the hazard of Città di Castello town. We selected two frequency bands $1-5 \mathrm{~Hz}$ and $5-10 \mathrm{~Hz}$ and estimated the average amplification factor at each station. The $1-5 \mathrm{~Hz}$ frequencies are traditionally relevant for the potential hazard of 23 storey buildings and the $5-10 \mathrm{~Hz}$ frequencies for 1 storey houses.

Our results (fig. 9) suggest that the center of the basin (i.e. the center of the town) has a maximum hazard level for 2-3 storey buildings with relative amplification factor up to 6. Moreover, the basin sides (especially the eastern edge) 


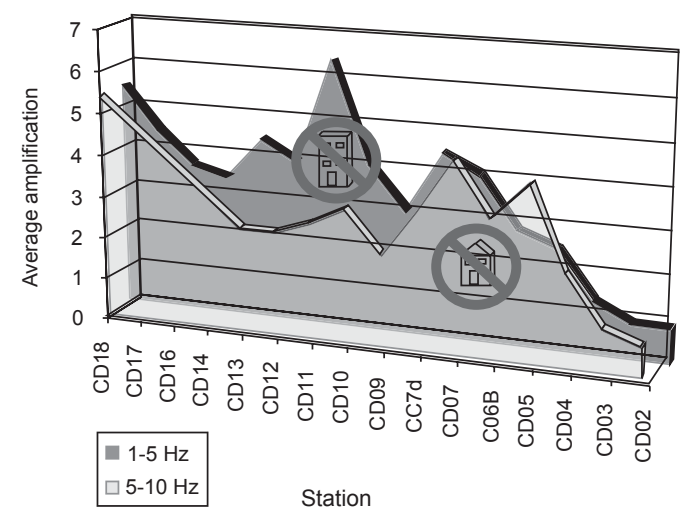

Fig. 9. Amplification values in the frequency band $1-5 \mathrm{~Hz}, 5-10 \mathrm{~Hz}$ at the sites along the EW transect. Our results suggest a potential hazard maximum in the center of the basin for 2-3 storey buildings, and at the edges for 1 storey houses.

show a maximum hazard level for 1 storey houses with relative amplification factor up to 5 .

\section{Discussion and conclusions}

The Città di Castello experiment was the second of the few dense site response experiments performed in Italy after Gaffet et al. (2000). Quite a large amount of data, both earthquakes and seismic noise, were collected during the deployment in only ten days. We not only instrumented a large number of sites with seismic stations that recorded continuously for the entire period, but we also installed temporary stations for noise measurements at about 200 sites in town. The narrow spacing between the stations and the continuous recording mode provide a unique data set to investigate the variation of ground motion over very small distances in the whole basin.

The amplitude variation of the $S$-waves across the transect and the delay time of $P$ - and $S$-phase arrivals suggest that the basin is deeper beneath CD12 (sediment depth of about 260 $\mathrm{m}$ ) and smoothly rises to the bedrock outcrop at the edges of the valley. Previous studies
(Pergalani et al., 2002a) made hypotheses on the bedrock depth and its topography, suggesting a maximum depth of about $240 \mathrm{~m}$ in the $\mathrm{NW}$ area of the town likely related to the emplacement of a east-dipping normal fault in the bedrock. However, our reconstruction of the bedrock geometry shows a more further west position of the deepest point and a smoother rise towards the edges.

We applied standard spectral ratios on earthquake data at stations along the EW profile to provide a detailed description of the relative site response variations inside the basin. We found amplification factors of up to 9 in the center of the basin (CD11-CD14) at frequency below $5 \mathrm{~Hz}$. The RU project estimated transfer functions at sites mainly inside the Citta di Castello town (de Franco et al., 2002; Pergalani et al., 2002b). Their analyses show that Città di Castello is generally characterized by a seismic amplification level of up to 5. This is comparable with the average amplification values we calculated in two bands of frequencies $(1-5 \mathrm{~Hz}$ and $5-10 \mathrm{~Hz}$ ) to evaluate the relevance of relative site response on the hazard of Città di Castello. We found a maximum hazard for 2 and 3 storey buildings in the center of the basin (relative amplification factor 6) and a maximum of hazard for 1 storey houses on the eastern side (relative amplification factor 5).

\section{Acknowledgements}

We would like to thank all the people involved in the deployment: G. Boniolo, A. Corsi, A. Morrone (IDPA); A. Antonioli, L. Badiali, P. Casale, E. Casarotti, B. Castello, C. Chiarabba, L. Chiaraluce, S. Cianetti, G. Colasanti, P. De Gori, A. Delladio, M. De Martin, R. Di Stefano, A. Frepoli, L. Giovani, C. Giunchi, P. Lucente, M. Marcocci, M. Mariucci, G. Mele, L. Mondiali, M. Moretti, M. Murru, M. Olivieri, N.M. Pagliuca, D. Pesaresi, S. Pondrelli, D. Piccinini, S. Pierdominici, C. Piromallo, F. Pirro, M. Pirro, A. Piscini, L. Scognamiglio, G. Selvaggi, G. Soldati and M. Silvestri (INGV); P. di Bartolomeo, S. Kravanjia, A. Govoni, A. Restivo, M. Romanelli 
(INOGS-CRS); L. Colaci, S. Cuttica, G. Ferretti, S. Iacono, D. Scafidi, C. Spagnolo and F. Zolezzi (Dip.Te.Ris.). We are grateful to A. Rovelli for important suggestions and discussions. Two anonymous referees provided relevant reviews, which helped to improve the manuscript. The Geological Survey of the Regione Umbria provided access to unpublished data. This study was funded by GNDT project 2000-2003 «Development and comparison among methodologies for the evaluation of seismic hazard in seismogenic areas: application to the Central and Southern Apennines» coordinated by M. Cocco.

\section{REFERENCES}

Amato, A., R. Azzara, C. Chiarabba, G.B. Cimini, M. Cocco, M. Di Bona, L. Margheriti, S. Mazza, F. Mele, G. Selvaggi, A. Basili, E. Boschi, F. Courboulex, A. Deschamps, S. Gaffet, G. Bittarelli, L. Chiaraluce, D. Piccinini and M. Ripepe (1998): The 1997 Umbria-Marche, Italy, earthquake sequence: a first look at the main shocks and aftershocks, Geophys. Res. Lett., 25, 2861-2864.

Augliera, P., M. Cattaneo and C. Eva (1995): Seismic multiplets analysis and its implication in seismotectonics, Tectonophysics, 248, 219-234.

Bonini, M. (1998): Chronology of deformation and analogue modelling of the Plio-Pleistocene 'Tiber Basin': implication for the evolution of the Northern Apennines (Italy), Tectonophysics, 285, 147-165.

BORCHERDT, R.D. (1970): Effects of local geology on ground motion near San Francisco Bay, Bull. Seismol. Soc. Am., 60, 29-61.

Boscherini, A., A. Motti, R. Rotili and A. Severi (2002): Microzonazione sismica in Alta Valtiberina Umbra: dati generali, inquadramento geomorfologico e rilevamenti di campagna, Ing. Sism., 1, 7-10 (in Italian with English abstract),

Cattaneo, M., P. Augliera, D. Spallarossa and V. Lanza (1999): A waveform similarity approach to investigate seismicity patterns, Natural Hazards, 19, 123-138.

Cattaneo, M., P. Augliera, G. De Luca, A. Gorini, A. Govoni, S. Marcucci, A. Michelini, G. Monachesi, D. Spallarossa, L. Trojani and XGUMS (2000): The 1997 Umbria-Marche (Italy) earthquake sequence: analysis of the data recorded by the local and temporary networks, J. Seismol., 4, 401-414.

Checcucci R., F. Ponziani and R. Rotili (2002): Microzonazione sismica in Alta Valtiberina Umbra: programmazione ed esecuzione delle indagini geologico-geotecniche e sismiche, Ing. Sism., 1, 11-14 (in Italian with English abstract).

Crespellani, T., C. Madiai and G. Simoni (2002): Indagini geotecniche per la valutazione degli effetti di sito in alcuni centri dell'Alta Valtiberina, Ing. Sism., 1, 15-32 (in Italian with English abstract).
Cultrera, G., A. Rovelli, A. Caserta, G. Mele and R.M. AzZARA (2003): Azimuth dependent amplification effects on weak and strong motions within a fault zone (Nocera Umbra, Central Italy), J. Geophys. Res., 108 (B3), 2156, doi:10.1029/2002JB001929.

de Franco, R., G. Caielli, A. Corsi and F. Ponziani (2002): Valutazione degli effetti di sito da dati sismologici in alcuni centri dell'Alta Valtiberina, Ing. Sism., 1, 57-65 (in Italian with English abstract).

Deschamps, A., F. Courboulex, S. Gaffet, A. Lomax, J. Virieux, A Amato, R. Azzara, B. Castello, C. Chiarabba, G.B. Cimini, M. Cocco, M. Di Bona, L. Margheriti, F. Mele, G. Selvaggi, L. Chiaraluce, D. PICCININI and M. RIPEPE (2000): Spatio-temporal distribution of seismic activity during the Umbria-Marche crisis, 1997, J. Seismol., 4, 377-386.

FIELD, E.H. (1996): Spectral amplification in a sediment filled valley exhibiting clear basin-edge induced waves, Bull. Seismol. Soc. Am., 86, 991-1005.

Gaffet, S., G. Cultrera, M. Dietrich, F. Courboulex, F. Marra, M. Bouchon, A. Caserta, C. Cornou, A. DeSCHAMPS, J.-P. GLOT and R. GUIGUET (2000): A site effect study in the Verchiano Valley during the 1997 Umbria-Marche (Central Italy) earthquakes, J. Seismol., 4, 525-541.

GELLER, R.J. and C.S. Mueller (1980): Four similar earthquakes in Central California, Geophys. Res. Lett., 7, 821-824.

GRUPPO DI LAVORO CPTI (1999): Catalogo Parametrico dei Terremoti Italiani (ING, GNDT, SGA, SSN, Bologna), pp. 92 (on-line http://emidius.mi.ingv.it/CPTI/).

HASKELL, N.A. (1953): The dispersion of surface waves in multi-layered media, Bull. Seismol. Soc. Am. 43, 27-34.

KenNET, B.L.N. and N.J. KeRRY (1979): Seismic waves in a stratified half space, Geophys. J. R. Astron. Soc., 57, 557-583.

MonACHESI, G. and M. STUCCHI (1997): DOM4.1, un database di osservazioni macrosismiche di terremoti di area italiana al di sopra della soglia del danno, Internal Report (GNDT, Milano-Macerata) (on line http://emidius.mi.ingv.it/DOM/).

NAKAMURA, Y. (1989): A method for dynamic characteristics estimations of subsurface using microtremors on the ground surface, Q. Rep. Railw. Tech. Res. Inst. Tokyo, 30, 25-33.

Nogoshi, M. and T. Igarashi (1970): On the propagation characteristics estimation of subsurface using microtremors on the ground surface, J. Seismol. Soc. Japan, 23, 264-280 (in Japanese with English abstract)

Nogoshi, M. and T. Igarashi (1971): On the amplitude characteristics of microtremor (Part 2), J. Seismol. Soc. Japan, 24, 26-40 (in Japanese with English abstract).

Pergalani, F., M. Compagnoni and V. Petrini (2002a): Valutazione degli effetti di sito tramite analisi numeriche e sperimentali nell'abitato di Città di Castello: analisi, confronti e utilizzo dei risultati, Ing. Sism., 1, 66-77 (in Italian with English abstract).

Pergalani, F., R. de Franco, M. Compagnoni and G. CAIELli (2002b): Valutazione degli effetti di sito di alcuni centri dell'Alta Valtiberina Umbra tramite modellazione numerica, Ing. Sism., 1, 44-56 (in Italian with English abstract) 
Piccinini, D., M. Cattaneo, C. Chiarabba, L. Chiaraluce, M. De Martin, M. Di Bona, M. Moretti, G. Selvaggi, P. Augliera, D. Spallarossa, G. Ferretti, A. Michelini, A. Govoni, P. Di Bartolomeo, M. RoMANELLI and J. FABBRI (2003): A microseismic study in a low seismicity area: the Città di Castello 2000-2001 experiment, Ann. Geophysics, 46 (6), 1315-1324 (this volume)

Poupinet, G., J. Fréchet, W.L. Ellsworth, M.J. Frémont and F. GLANGEAUD (1985): Doublet analysis: improved accuracy for earthquake prediction studies, Earthquake Predict. Res., 3, 147-159.

Thompson, W.T. (1950): Transmission of elastic waves through a stratified solid medium, J. Appl. Phys., 21, 89-143.

(received July 22, 2003; accepted December 18, 2003 